Parliamentary Secretary to the Minister for Science

IN moving the second reading of the Ministers of the Crown (Parliamentary Secretaries) Bill in the House of Commons on November 18, the Financial Secretary to the Treasury, Sir Edward Boyle, said that the Bill was designed first and foremost to give the Government greater flexibility in the deployment of Parliamentary Secretaries between Departments, and also, more specifically, it authorized the payment of a salary, not exceeding $£ 2,500$ a year, to a Parliamentary Secretary to the Minister for Science. He would be Parliamentary Secretary to the Minister and not to the Ministry, and if the appointment was made questions falling within the responsibility of the Minister would be answered in the House of Commons by the Parliamentary Secretary. Dr. R. Bennett, speaking as chairman of the Parliamentary and Scientific Committee, welcomed the provision as something for which that Committee had been pressing and also paid a generous tribute to the ability of the present Minister for Science. In replying on the debate, Sir Edward Boyle suggested that provision of a Parliamentary Secretary would assist the Minister to pursue his studies in greater detail and that the Parliamentary Secretary would also be able to reply to debates on all the main subjects for which the Minister was responsible. These responsibilities embraced first the Atomic Energy Authority ; secondly, the four main executive research councils; and thirdly, those very important advisory bodies, the Advisory Couneil on Scientific Policy, with its Scientific Man-power Committee, the Overseas Research Council, and the Steering Group for Space Research. If, on the adjournment, members wished to raise the whole question of the work of the Department of Scientific and Industrial Research, or of the advisory bodies, there would be a junior Minister responsible for replying specifically on these subjects.

\section{British Patents and Designs}

ON moving the second reading of the Patents and Designs (Renewals, Extensions and Fees) Bill in the House of Lords on November 15, the Earl of Dundee explained that while the Industrial Property Convention of October 1958 made some improvements in existing practice, the only one which needed legislation in Great Britain was the proposed extension from three months to six months in the period of grace allowed for the application for a renewal of a patent or copyright protection for a design. This is done under Clause 1 of the Bill, which also corrects a mistake inadvertently in our own Registered Designs Act but not in the Patents Act of 1949 . Clause 2 proposes to repeal the first schedule to the Patents Act, 1949 , which specifies certain maximum fees for the registration and renewal of patents but not designs and not trade marks. This schedule to the Act of 1949 is identical with that in the Patents and Designs Act, 1884, and the Earl of Dundee said that it was not proposed to control fees under a statutory instrument as was already done for trade marks or designs, in place of introducing a new schedule. He indicated that if the Bill was passed in its present form the Patent Office proposed to increase the application fee for a patent from $£ 1$ to $£ 2$, and that for filing the complete specifieation from $£ 4$ to $£ 8$. Nearly all the expenses of the Patent Office were in connexion with filing the initial application and the complete specification, and it was proposed to make no increase in the renewal fees, which varied from a maximum of $£ 5$ in the first year to $£ 20$ in the sixteenth year, and were mostly still less than the set maxima. While welcoming the first part of the Bill, Lord Silkin urged strongly that the clause relating to revised fees should be withdrawn and introduced as a specific single-clause measure, and this was also supported by Lord Cowley and Lord Ferrier, the former of whom thought the present Clause 2 was contrary to the advice of the Swan Committee in 1947. In his reply, the Earl of Dundee maintained that the procedure proposed by the Government was the most advantageous, and said that the Government had already discussed the matter with interested commercial organizations, none of which had raised any objections to the fixing of fees by statutory instruments rather than by a schedule in an act of Parliament.

\section{International Patent Conventions}

The Catalogue of the Derwent Information Service describes briefly the various publications and services provided (Derwent Patents Abstracts-Catalogue. Pp. ii +38. London: Derwent Information Service, Theobalds Road, W.C.1, 1960. 2s. 6d.). These include reports on British, German, Commonwealth, Belgian and Russian patents in certain specified fields, journals containing abstracts of fine chemicals, plastics, petrochemicals and metallurgical patents, and a series of other patents bulletins dealing with more limited fields. Besides information on patenting procedure in various countries, the catalogue includes an article by M. Hyams on Russian patent law and procedure based on discussions with the Committee for Inventions in Moscow.

\section{Museum of Science and Industry, Birmingham}

Birmingham City Council recently approved a scheme for extending the Museum of Science and Industry in Newhall Street. The new building will replace old property which is structurally unsound and increase the floor area of the Museum to 150,000 sq. $\mathrm{ft}$. The whole scheme is estimated to cost $£ 590,000$ and will take not less than six years to complete. The work of rebuilding will be undertaken in three phases; these comprise the erection of a galleried single-storey unit to house, among other large exhibits, the Pacific locomotive City of Birmingham; a sixstorey administrative, workshop and stores block and another single-storey unit with galleries, in that order. Provision has been made for a lecture room, two cafes and numerous rest rooms. When the scheme is completed publie access will be from Fleet Street (which runs at right angles to Newhall Street) by a bridge over the Birmingham-Fazeley Canal.

The site and buildings now occupied by the Museum were once the premises of Elkington and Co., Ltd. (who are well known for the manufacture of silverplate), until they were taken over by the Committee of the City Museum and Art Gallery in 1950 to house the newly formed Department of Science and Industry. During the past ten years the old factory has been systematically adapted for Museum purposes and opened to the public as each section was completed. The Museum exhibits small arms, veteran, vintage and modern motor-cars and motor-cycles, machine tools, steam engines which are run periodically on live steam, internal combustion engines and scientifio instruments covering a wide field. The annual attendances now exceed 400,000 . 